\title{
Konsep Pendidikan Anak Menurut Al-Qur'an Surat Lukman Ayat 13-19
}

\author{
Subhan \\ STKIP Taman Siswa Bima \\ subhantanjung@gmail.com
}

\begin{abstract}
ABSTRAK
Al-Qur'an merupakan firman Allah yang selanjutnya di jadikan pedoman hidup (way of life) kaum muslim yang tidak ada lagi keraguan di dalamnya. Di dalamnya terkandung ajaran-ajaran pokok (prinsip dasar) menyangkut segala aspek kehidupan manusia yang selanjutnya dapat dikembangkan sesuai dengan nalar masing-masing bangsa dan kapanpun masanya dan hadir secara fungsional memecahkan problem kemanusiaan. Manusia dalam kenyataan hidupnya menunjukan bahwa ia membutuhkan suatu proses belajar yang memungkinkan dirinya untuk menyatakan eksistensinya secara utuh dan seimbang. Manusia tidak dirancang oleh Allah SWT. untuk dapat hidup secara langsung tanpa proses belajar terlebih dahulu untuk memahami jati dirinya dan menjadi dirinya. Dalam proses belajar itu seseorang saling tergantung dengan orang lain. Proses belajar itu dimulai dengan orang terdekatnya. Proses belajar itulah yang kemudian menjadi basis pendidikan. Ketidakberhasilan tertanamnya nilai-nilai rohaniyah (keimanan dan ketaqwaan) terhadap peserta didik (murid) dewasa ini sangat terkait dengan dua faktor penting dalam proses pembelajaran di samping banyak faktor-faktor yang lain, kedua faktor tersebut adalah strategi pembelajaran serta orang yang menyampaikan pesan-pesan ilahiyah (guru). Dalam sistem pendidikan Islam seharusnya menggunakan metode pendekatan yang menyeluruh terhadap manusia, meliputi dimensi jasmani dan rohani (lahiriyah dan batiniyah), di samping itu keberhasilan sebuah proses pembelajaran sangat ditunjang oleh kepribadian setiap penyampai pesan (guru). Materi pendidikannya mencakup pendidikan Aqidah, pendidikan Syari'ah dan pendidikan Akhlak. Metode pengajarannya dengan mauidloh dan tanya jawab. Sifat pendidik mencakup bijaksana dan kasih sayang terhadap anak didik.
\end{abstract}

Kata Kunci: Konsep Pendidikan, Al-Qur'an.

\section{PENDAHULUAN}

Al-Qur'an merupakan firman Allah yang selanjutnya di jadikan pedoman hidup (way of life) kaum muslim yang tidak ada lagi keraguan di dalamnya. Di dalamnya terkandung ajaranajaran pokok (prinsip dasar) menyangkut segala aspek kehidupan manusia yang selanjutnya dapat dikembangkan sesuai dengan nalar masingmasing bangsa dan kapanpun masanya dan hadir secara fungsional memecahkan problem kemanusiaan (Zakiah Daradjat: 2002).

Petunjuk pendidikan dalam al-Qur'an tidak terhimpun dalam kesatuan pragmen tetapi ia diungkapkan dalam berbagai ayat dan surat alQur'an, sehingga untuk menjelaskannya perlu melalui tema-tema pembahasan yang relevan dan ayat-ayat yang memberikan informasi-informasi pendidikan yang dimaksud.

Petunjuk-petunjuknya bertujuan memberi kesejahteraan dan kebahagiaan bagi manusia, baik secara pribadi maupun kelompok, dan karena itu ditemukan petunjuk-petunjuk bagi manusia dalam kedua bentuk tersebut. Muhammad Rasulullah dipandang sukses dalam mendidik masyarakatnya menjadi masyarakat yang berbudi tinggi dan akhlak mulia. Pada mulanya masyarakat Arab adalah masyarakat jahiliyah, sehingga perkataan primitif tidak cukup untuk menggambarkannya, hingga datang Rasulullah yang membawa mereka untuk meninggalkan kejahiliahan tersebut dan mencapai suatu bangsa yang berbudaya dan berkepribadian yang tinggi, bermoral serta memberi bengetahuan.

Di lihat dari segi tanggung jawab, orang tua adalah orang yang paling bertanggung jawab terhadap pendidikan anak. Anak dilahirkan dan dibesarkan oleh orang tua, orang yang pertama kali dijumpai anak adalah orang tuanya, jadi secara tidak langsung ayah dan ibu adalah guru 
pertama bagi anak, disadari atau tidak oleh orang tua itu sendiri (Achmad Djazuli: 2005).

Seharusnya disaat para orang tua menanti kelahiran anaknya bahkan jauh sebelum itu, di saat merencanakan sebuah pernikahan mereka sudah merancang bagai mana pola asuh dan metode apa yang akan digunakan untuk mendidik dan membimbing anak-anaknya kelak. Ibarat seorang calon guru yang sedang kuliah mempelajari tentang seluk beluk menjadi seorang pendidik.

Kenyataan yang terlihat dikehidupan yang serba canggih dan serba materi ini, hal yang paling dikhawatirkan para orang tua bukan masalah pendidikan tapi masalah uang. Di saat anak lahir kedunia ini yang jadi pikirkan orang tua (kebanyakan), apakah nanti ada uang untuk beli susu anak, apakah nanti bisa membahagiakan anak dengan membelikan apa yang dimintanya.

Sementara dalam al-Qur'an sendiri telah memberi isyarat bahwa permasalahan pendidikan sangat penting, jika al-Qur'an dikaji lebih mendalam maka kita akan menemukan beberapa prinsip dasar pendidikan, yang selanjutnya bisa kita jadikan inspirasi untuk dikembangkan dalam rangka membangun pendidikan yang bermutu. Ada beberapa indikasi yang terdapat dalam al-Qur'an yang berkaitan dengan pendidikan antara lain; Menghormati akal manusia, bimbingan ilmiah, fitrah manusia, penggunaan cerita (kisah).

Manusia dalam kenyataan hidupnya menunjukan bahwa ia membutuhkan suatu proses belajar yang memungkinkan dirinya untuk menyatakan eksistensinya secara utuh dan seimbang. Manusia tidak dirancang oleh Allah SWT. untuk dapat hidup secara langsung tanpa proses belajar terlebih dahulu untuk memahami jati dirinya dan menjadi dirinya. Dalam proses belajar itu seseorang saling tergantung dengan orang lain. Proses belajar itu dimulai dengan orang terdekatnya. Proses belajar itulah yang kemudian menjadi basis pendidikan.

Aktivitas pendidikan terkait dengan perubahan yang secara moral bersifat lebih baik, ciri perubahan atau kemajuan secara fundamental adalah terjadinya perkembangan internal diri manusia yaitu keimanan dan ketaqwaan, bukan hanya perubahan eksternal yang cenderung bersifat material yang dapat menghancurkan keimanan dan ketaqwaan manusia.

Dalam kehidupan modern seperti sekarang ini, produk pendidikan sering hanya diukur dari perubahan eksternal yaitu kemajuan fisik dan material yang dapat meningkatkan pemuasan kebutuhan manusia. Masalahanya adalah bahwa manusia dalam memenuhi kebutuhan sering bersifat tidak terbatas, bersifat subyektif yang sering justru dapat menghancurkan harkat kemanusiaan yang paling dalam yaitu kehidupan rohaninya. Produk pendidikan berubah menghasilkan manusia yang cerdas dan terampil untuk melakukan pekerjaannya, tetapi tidak memiliki kepedulian dan perasaan terhadap sesama manusia. Ilmu pengetahuan yang dikembangkan menjadi instrumen kekuasaan dan kesombongan untuk memperdayai orang lain, kecerdikannya digunakan untuk menipu dan menindas orang lain, produk pendidikan berubah menghasilkan manusia yang serakah dan egois.

Ketidakberhasilan tertanamnya nilai-nilai rohaniyah (keimanan dan ketaqwaan) terhadap peserta didik (murid) dewasa ini sangat terkait dengan dua faktor penting dalam proses pembelajaran di samping banyak faktor-faktor yang lain, kedua faktor tersebut adalah strategi pembelajaran serta orang yang menyampaikan pesan-pesan ilahiyah (guru). Dalam sistem pendidikan Islam seharusnya menggunakan metode pendekatan yang menyeluruh terhadap manusia, meliputi dimensi jasmani dan rohani (lahiriyah dan batiniyah), di samping itu keberhasilan sebuah proses pembelajaran sangat ditunjang oleh kepribadian setiap penyampai pesan (guru).

Dari uraian diatas, maka penulis tertarik ingin meneliti lebih jauh mengenai "Konsep Pendidikan Anak Menurut Konsep Al-Qur'an Surat Lukman Ayat 13-19.

\section{Pengertian Pendidikan Islam}

Dari berbagai literatur terdapat berbagi macam pengertian pendidikan Islam. Menurut Athiyah Al-Abrasy, pendidikan Islam adalah 
mempersiapkan manusia supaya hidup dengan sempurna dan bahagia, mencintai tanah air, sehat jasmaninya, sempurna budi pekertinya, pola pikirnya teratur dengan rapi, perasaannya halus, profesiaonal dalam bekerja dan manis tutur sapanya.

Sedang Ahmad D. Marimba memberikan pengertian bahwa pendidikan Islam adalah bimbingan jasmani dan rohani berdasarkan hukum-hukum islam menuju kepada terbentuknya kepribadian utama menurut ukuran-ukuran Islam.

Sedangkan menurut Sayed Muhammad Naquib Al-Attas, pendidikan adalah suatu proses penanaman sesuatu ke dalam diri manusia mengacu kepada metode dan sistem penamaan secara bertahap, dan kepada manusia penerima proses dan kandungan pendidikan tersebut.

Dari definisi dan pengertian itu ada tiga unsur yang membentuk pendidikan yaitu adanya proses, kandungan, dan penerima. Kemudian disimpulkan lebih lanjut yaitu "sesuatu yang secara bertahap ditanamkan ke dalam diri manusia".

Jadi definisi pendidikan Islam adalah, pengenalan dan pengakuan yang secara berangsur-angsur ditanamkan ke dalam diri manusia, tentang tempat-tempat yang tepat dari segala sesuatu di dalam tatanan penciptaan, sehingga membimbing ke arah pengenalan dan pengakuan tempat Tuhan yang tepat di dalam tatanan wujud dan kepribadian.

Dalam pandangan Al-Attas pendidikan Islam harus terlebih dahulu diberikan kepada manusia sebagi peserta didik, pendidikan tersebut berupa pengetahuan tentang manusia disusul dengan pengetahuan-pengetahuan lainnya. Dengan demikian dia akan tahu jati dirinya dengan benar, tahu "dari mana dia, sedang dimana dia, dan mau kemana dia kelak". Jika ia tahu jati dirinya, maka ia akan selalu ingat dan sadar serta mampu dalam memposisikan dirinya, baik terhadap sesama makhluk, dan yang terlebih lagi kepada Allah SWT. Ketiga realita yaitu, manusia, alam, dan Tuhan diakui keberadaannya, dengan Tuhan sebagai sumber dari segalanya (alam dan manusia).
Tuhan dapat dipahami sebagaimana diinformasikan dalam Al-Quran sebagi Rabb alAlamin, dan Rabb al-Nass. Amrullah Ahmad menilai bahwa dalam definisi pendidikan AlAttas mengandung proses pengajaran seseorang dalam tatanan kosmis dan sosial yang akan mengantarkannya untuk menemukan fungsinya sebagi kholifah.

\section{Keluarga Dan Pendidikan Anak}

Peran ayah muslim dalam kehidupan anaknya adalah hal yang palin penting. Al-Quran dan hadits meneyebutkan ayah sebagai kepala keluarga, penanggung jawab pemenuhan kebutuhan ekonomi, pendidikan, dan penguasa. Bahkan peran seorang ayah terlihat sangat jelas daripada peran ibu karena lebih banyak terlihat dalam aktifitas social dari pada wanita. Seperti yang telah kita lihat, Al-Quran menunjukan beberapa contoh dari ayah yang men jadi Nabi, seperti Lukman menuntun anaknya dan melaksanakan fungsinya kebapakkanya dengan keadilannya, kebijaksanaan dan kebenaran

Berdasarkan tingginya status ibu dalam Islam, lebih tinggi dari ayah maka kita sangat mudah untuk memahami mengapa wanita muslimah menginginkan anak dan mengapa mereka bahagia tianggal di rumah dan suka memberi perhatian pada anak-anaknya. Seorang ibu bisa sja b ekerja pada saat anak-anak berkembang. Namun demikian, ketika diperlukan, bisa saja ambil ibu angkat atau kerabat yang lain dapat mengantikan posisi ibu, dalam waktu sementara atau waktu yang lama. Dalam banyak kasus, usaha untuk memenuhi kebutuhan keluarga, menciptakan kehangatan, cinta, suasana yang penuh damai dengan segala masalah pribadi dan sifat yang terdapat dalam anggota keluarga, membutuhkan banyak hal. Tidak bisa dipungkiri, semua ini adalah jihad yang sesungguhnya bagi kaum wanita. Nabi saw bersabda : "Setiap orang dari kamu adalah pemimpin dan setiap kamu juga bertanggung jawab terhadap apa yang dipimpin. Imam adalah pemimpin dan bertanggung jawab terhadap mereka; suami adalah pemimpin keluarga dan bertanggung jawab pada kelurganya, wanita adalah pemimpin dalam rumah suaminya dan bertanggung jawab untuk itu; pelayan adalah pemimpin bagi kekayaan 
majikannya dan bertanggung jawab untuk itu." (HR. Bukhari, 329).

Ketika wanita memenuhi peranya sebagai pengasuh dan pria sebagai pelindungnya, maka masyarakat akan menjadi baik; ketika wanita dan pria tidak menjalankan peranny, masyarakat akan jatuh. Dan masyarakat juga mengakui dan mendukung hal ini ndengan menjadikan bantuan bagi orang tua dalam menjalankan perannya yang utama.

\section{Metode Pendidikan Anak}

Anak dilahirkan tidak dalam keadan lengkap dan tidak pula dalam keadaan kosong. Ia dilahirkan dalam keadaan fitrah. Memang ia dilahirkan dalam keadaan tidak tahu apa-apa, akan tetapi anak telah dibekali dengan pendengaran, penglihatan, dan kata hati.

Dengan diberikannya penglihatan, pendengaran, dan kata hati tersebut, diharapkan orang tua harus mampu membimbing, mengarahkan, dan mendidiknya dengan ekstra hati-hati karena anak sebagai peniru yang ulung. Oleh karena itu semaksimal mungkin orang tua memberikan pelayanan terhadap anaknya. Pelayanan yang maksimal akan menghasilkan suatu harapan bagi bapak ibunya, tiada lain suatu kebahagiaan hasil jerih payahnya. Sebab anak adalah sumber kebahagiaan, kesenangan, dan sebagai harapan dimasa yang akan datang. Harapan-harapan orang tua akan terwujud, tatkala mereka mempersiapkan sedini mungkin pendidikan yang baik sebagai sarana pertumbuhan dan perkembangan bagi anak.

Memang diakui bahwa mengemudikan bahtera rumah tangga yang baik, yang sakinah, dan yang maslahah merupakan tugas kewajiban yang sangat rumit, tidak kalah rumitnya dengan mengelola sebuah pabrik, dan tidak kalah canggihnya dengan mengemudikan pesawat terbang karena orang tua harus siap untuk memperpadukan sekian banyak unsur dan dimensi mulai dari dimensi sikap mental, ilmu pengetahuan, ketrampilan dan lain sebagainya. Sebagai kewajiban dari orang tua, dalam hal ini adalah pemegang amanat, maka barang siapa yang mampu menjaga amanat tersebut akan diberi pahala, dan sebaliknya. Hal ini sesuai dengan janji Allah SWT dalam firmanya, QS.al-Kahfi (18) : 46.

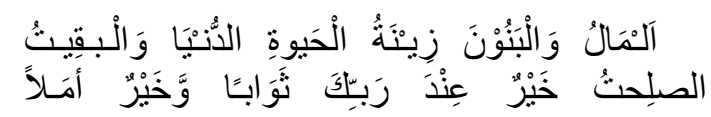

(الكهن:(46)

Artinya : "Harta dan anak-anak adalah perhiasan kehidupan dunia, tetapi amalanamalan yang kekal lagi saleh adalah lebih baik pahala disisi Tuhanmu serta lebih baik untuk menjadi harapan”. (QS. Al-Kahfi : 46).

Dalam mendidik anak, tentunya harus ada kesepakatan antara bapak ibu sebagai orang tua, akan dibawa kepada pendidikan yang otoriter atau pendidikan yang demokratis atau bahkan yang liberal, sebab mereka penentu pelaksana dalam keluarga.

Dalam kehidupan masyarakat terkecil, yaitu keluarga, suami secara fungsional adalah penanggung jawab utama rumah tangga (keluarga) sedangkan istri adalah mitra setia yang aktif konstruktif mengelola rumah tangga. Operasionalisasi kehidupan berkeluarga sebaiknya dilakukan berdasarkan amar makruf nahi munkar.

Salah satu wujud amar makruf nahi munkar dalam kehidupan berkeluarga adalah memberikan pendidikan kepada putra putrinya berdasarkan ajaran Islam. Antara keluarga satu dengan keluarga lainnya mempunyai prinsip dan sistem sendiri-sendiri dalam mendidik anaknya. Namun orang tua jangan terbuai atau melupakan terhadap ajaran-ajaran Islam, terutama dalam hal pendidikan anak sebagaimana yang telah dicontohkan Rasul saw. sebagai pembawa panji-panji Islam, Rasul SAW tidak pernah mendidik putra-putrinya dengan pendidikan keras dan tidak dengan membebaskan anak-anaknya, tetapi beliau dalam mendidik keluarganya terutama kepada anak-anaknya adalah dengan limpahan kasih sayang yang amat besar. Senada dengan yang dikatakan oleh sahabat Anas ra. yaitu "aku tidak mendapatkan seseorang yang kasih sayangnya pada keluarganya melebihi Rasulullah SAW."

Seorang muslim sepatutunya mencontoh teladan yang telah diberikan Rasul SAW, dalam memuliakan putra putrinya. Beliau dalam mendidik anak-anaknya melalui ajaran wahyu Ilahi yaitu dengan penuh kasih sayang terhadap anak-anaknya. Dengan pemberian kasih sayang tersebut, diharapkan dapat menunjang pertumbuhan dan perkembangan anak. Sebab 
anak merupakan aset masa depan. Sebagai orang tua dapat meneladani ajaran-ajaran Rasul SAW tersebut, melalui para pemikir dan pemerhati pendidikan (anak) dalam Islam. Salah satu pemerhati pendidikan (anak) dalam Islam yang memberikan gambaran yang benar sesuai dengan ajaran Islam adalah Ulwan. Ia memberikan pandangannya dalam mendidik anak dalam keluarga melalui metode-metode yang harus diterapkan dalam pendidikan anak termasuk dalam hal pendidikan moral. Apabila metode-metode tersebut diterapkan, niscaya apa yang menjadi harapan bersama sebagai muslimin yaitu tumbuhnya para generasi Islam yang tangguh dan sebagai penebar kebenaran, dapat direalisasikan.

Untuk mmemperoleh hasil yang baik dalam pelaksanaan pendidikan (moral) maka harus memenuhi beberapa faktor-faktornya. Salah satu faktornya adalah metode. Metode merupakan sarana untuk menyampaikan isi atau materi pendidikan tersebut, agar tujuan yang diharapkan dapat tercapai dengan hasil yang baik.

\section{METODE}

\section{Jenis Penelitian}

Jenis penelitian ini merupakan penelitian library research, maka pengumpulan datanya merupakan telaah atau kajian pustaka yang berupa data verbal atau sekunder dalam bentuk kata, bukan dalam bentuk angka.

\section{Sumber data}

Data primer yaitu sumber data asli dari permasalahan yang akan diteliti. Yang termasuk sumber data primer adalah buku-buku mengenai konsep pendidikan anak menurut konsep alQur'an surat Lukman ayat 13-19 yang berhubungan dengan penelitian.

Data sekunder yaitu sumber data dari bukubuku karangan seseorang (buku data asli) tentang permasalahan yang akan diteliti. Adapun sumber data sekunder diperoleh dari berbagai buku-buku dan artikel-artikel majalah yang ditulis oleh tokoh-tokoh yang relevan dan menunjang penelitian ini.

\section{Teknik Analisis Data}

Penelitian ini bersifat kualitatif dengan menggunakan metode deskriptif analitis, sedangkan dalam pembahasannya menggunakan metode berpikir induktif dan deduktif.

Metode induktif yaitu metode berpikir yang berangkat dari masalah-masalah yang bersifat umum kemudian ditarik kesimpulan yang bersifat khusus.

Metode deduktif yaitu metode berpikir yang berangkat atau bertitik tolak dari hal-hal yang bersifat khusus dirangkaian menjadi pemecahan yang bersifat umum.

\section{HASIL PENELITIAN}

\section{Biografi Luqman}

Biografi Lukmanul Hakim Dalam buku berjudul "Lukmanul Hakim, kepribadian dan Mutiara Hikmahnya"Ali bin Hasan bin Abdullah bin Hasan bin Umar Al-Athas menuliskan tentang asal-usul Luqmanul Hakim dari berbagai versi yang mana satu sama lain berbeda pendapat tentang asal-usul Luqmanul Hakim. Ibnu Ishak berpendapat bahwa Luqmanul Hakim adalah Luqman bin Baura bin Nahur bin Tariha sedangkan Tariha adalah Azar, ayah Ibrahim as. Assuhaailybahawa Luqmanul Hakim adalah putra Unga bin Sarun dari penduduk Aylah Palestina. Wahab mempunyai pendapat lain, bahwa Luqmanul Hakim itu putra saudari Ayyub as. Tetapi menurut pendapat yang dinukil dari Muqotil beliau adalah putra Ayyub as. Konon Luqmanul Hakim hidup selama seribu tahun semasa dengan Dawud as. Sebelum Dawud as di utus Lukmanul Hakim memberi fatwa kepada manusia, namun setelah Dawud as diutus, beliau tidak lagi memberikan fatwa. Waqidi berpendapat bahwa Luqmanul Hakim itu adalah sebagai Qadhi (hakim) di kalangan Bani Israil. Sebagian besar ulama berpendapat bahwa Lukmanul Hakim itu hamba sahaya (budak) dari negri Habsyi (Ethiopia). Ibnu Abil Qosim meriwayatkan dari Abdullah bin Azzubair, katanya: "Aku bertanya kepada Jabir bin Abdillah, apa yang engkau ketahui tentang Lukman?. ia menjawab "Beliau adalah orang yang berbadan pendek, berhidung pesek dari negri Negro". Luqmanul hakim bekerja sebagai tukang jahit. Ada yang berpendapat beliau adalah tukang kayu. Dan ada juga yang 
berpendapat bahwa Luqman itu adalah sebagai pengembala kambing.

Sebagian para ahli berpendapat bahwa "Luqmanul Hakim itu seorang yang arif budiman, bukan seorang nabi. Imam AnNawawi dalam kitab al-Adzar menulis, bahwa Luqman dan Maryam bukanlah nabi. Sebenarnya kedua-duanya itu adalah tergolong sebagai Shiddiqin".

Konon beliau disuruh memilih antara kenabian dan hikmah lantas beliau memilih hikmah. Diriwayatkan bahwa Jibril as ketika menyuruh Luqmanul Hakim untuk memilih antara kenabian dan hikmah, maka beliau memilih hikmah. Seraya Jibril mengusap dada Luqman Hakim dengan sayapnya, lalu Luqman Hakim berbicara dengan mutiara hikmah "Ketika Jibril berpamitan ia berbicara kepada Luqmanul Hakim" Aku berwasiat kepadamu dengan wasiat, maka jagalah wasiatku ini, wahai Lukman : Sekiranya engkau masukan tanganmu sampai sakumu kedalam mulut ular besar, maka hal itu lebih baik bagimu daripada engkau meminta-minta seperti seorang fakir yang merasa kaya. Luqman mempunyai putra bernama Taran sebagaimana dikemukakan oleh Ath-Thabari, juga ada yang mengatakan Tsaran atau Anum atau Masykum. "Ada yang mengatakan bahawa putra Luqman itu seorang kafir yang musyirik. Oleh karena itu Luqman selalu tak henti-henti memberi nasihat shingga ia memeluk agama Islam".

Perbedaan Ucapan Luqman Dengan Firman Allah

Secara tekstual ayat-ayat ini memang berbicara secara khusus tentang pesan Luqman dalam konteks mendidik anak sesuai dengan pesan alQur'an. Apalagi pesan Luqman dalam surat ini sebenarnya adalah pesan Allah yang dibahasakan melalui lisan Luqman Al-Hakim sehingga sifatnya mutlak dan mengikat ; pesan Luqman dalam bentuk perintah berarti perintah Allah, demikian juga nasehatnya dalam bentuk larangan pada masa yang sama adalah juga larangan Allah yang harus dihindari.

\section{Nasehat Luqman}

Satu-satunya manusia yang bukan nabi pada jamannya, bukan pula Rasul tapi kisah hidupnya diabadikan dalam al-Qur'an adalah Luqman Al Hakim. Kenapa, tak lain, karena hidupnya penuh hikmah. Suatu hari ia pernah menasehati anaknya tentang hidup.

1) Wahai anakku! Elakkan dirimu dari berhutang kerana sesungguhnya dengan berhutang itu akan menjadikan dirimu hina diwaktu siang hari dan menjadikan dirimu gelisah di waktu malam hari.

2) Wahai anakku! Sekiranya kedua ibu bapamu memarahimu kerana sesuatu kesalahan yang telah kamu lakukan maka kemarahan kedua mereka itu adalah seperti baja untuk menyuburkan tanaman.

3) Wahai anakku! Engkau akan dapat rasakan betapa beratnya ketika mengangkat batu yang besar atau besi yang padat tetapi ada yang lebih berat dari itu iaitu apabila kamu mempunyai jiran tetangga yang jahat.

4) Wahai anakku! Tidaklah dinamakan kebaikan sekalipun kamu sibuk mencari dan mengumpul ilmu pengetahuan tetapi tidak pernah mengamalkannya. Perbuatan ini tak ubah seperti seorang pencari kayu api yang sentiasa menambah timbunan kayunya sedangkan ia tidak mampu untuk mengangkatnya.

5) Wahai anakku! Berhati-hatilah terhadap tutur tata dan bicaramu, peliharalah budi bahasamu dan sentiasalah bermanis muka nescaya kamu akan disenangi dan disukai oleh orang yang berada di sekelilingmu. Perumpamaannya seolah mereka telah mendapat barang yang amat berharga darimu.

6) Wahai anakku! Jika kamu mahu mencari sahabat sejati maka kamu ujilah ia terlebih dahulu dengan berpura-pura membuatkan ia marah terhadapmu. Sekiranya dalam kemarahan itu ia masih mahu menasihati, menyedarkan dan menginsafkan kamu, maka dialah sahabat yang dicari. Jika berlaku sebaliknya maka berwaspadalah kamu terhadapnya.

7) Wahai anakku! Bila kamu mempunyai teman yang karib maka jadikanlah dirimu sebagai seorang yang tidak mengharapkan sesuatu apapun darinya sebaliknya biarkanlah 
temanmu itu sahaja yang mengharapkan sesuatu darimu.

8) Wahai anakku! Jagalah dirimu selalu supaya tidak terlalu condong kepada dunia dan segala kesenangan dan kemewahannya kerana Allah tidak menciptakan kamu hanya untuk kehidupan di dunia sahaja. Ketahuilah tidak ada makhluk yang lebih hina selain dari mereka yang telah diperdayakan oleh dunia.

9) Wahai anakku! Janganlah kamu ketawa jika tiada sesuatu yang menggelikan, janganlah kamu berjalan jika tiada arah hala tujuan, janganlah kamu bertanya tentang sesuatu yang tidak memberi apa-apa faedah pun kepadamu dan janganlah kamu mengsiasiakan hartamu pada jalan maksiat.

10) Wahai anakku! Siapa yang bersifat penyayang sudah tentu dia akan disayang, siapa yang bersifat pendiam sudah tentu dia akan selamat dari mengeluarkan perkataan yang sia-sia. Ketahuilah sesiapa yang tidak dapat menahan lidahnya dari mengeluarkan ucapan kotor, sudah tentu ia akan menyesal kelak.

11) Wahai anakku! Bergaul dan berkawanlah dengan orang-orang yang soleh dan berilmu. Bukalah pintu hatimu dan dengarlah segala nasihat dan tunjuk ajar darinya. Sesungguhnya nasihat dari mereka bagaikan mutiara hikmah yang bercahaya yang dapat menyuburkan hatimu seperti tanah kering lalu disirami air hujan.

12) Wahai anakku! Sesungguhnya kehidupan kita ini diibaratkan seperti sebuah kapal yang belayar di lautan dalam dan telah banyak manusia yang karam didalamnya. Jika kita ingin selamat maka belayarlah dengan kapal yang bernama takwa, isi kandungannya ialah iman sedang layarnya pula ialah tawakal kepada Allah.

13) Wahai anakku! Bila kamu menerima dua undangan majlis, satu majlis perkahwinan dan satu lagi majlis takziah kematian, maka utamakanlah majlis kematian kerana dengan menghadiri majlis ini akan mengingatkan kamu kepada kampung akhirat, sedangkan dengan menghadiri majlis perkahwinan akan mengingatkan kamu kepada keseronokkan dunia sahaja.

14) Wahai anakku! Janganlah kamu terus menelan apa saja yang kamu rasa manis dan meludah setiap apa yang kamu rasa pahit. Ingatlah, tidak semua yang manis itu akan menjadikan kita segar dan tidak semua yang pahit itu akan menjadikan kita segar.

15) Wahai anakku! Janganlah kamu makan dengan terlalu kenyang yang berlebihlebihan. Sesungguhnya adalah lebih baik jika bahagian dari yang kenyang itu diberikan kepada anjing sahaja.

16) Anakku, jika makanan telah memenuhi perutmu, maka akan matilah pikiran dan kebijaksanaanmu. Semua anggota badanmu akan malas untuk melakukan ibadah, dan hilang pulalah ketulusan dan kebersihan hati. Padahal hanya dengan hati bersih manusia bisa menikmati lezatnya berdzikir.

17) Anakku, kalau sejak kecil engkau rajin belajar dan menuntut ilmu. Dewasa kelak engkau akan memetik buahnya dan menikmatinya.

18) Wahai anakku! Carilah harta di dunia ini sekadar keperluanmu sahaja dan nafkahkanlah hartamu yang selebihnya pada jalan Allah sebagai bekalmu di akhirat. Janganlah kamu membuat dunia ini tujuan, kelak dirimu akan menjadi pengemis dan membebankan pula orang lain tetapi jangan pula kamu terlalu mengejar dunia sehingga terlupa bahawa kamu akan mati. Ketahuilah, apa yang kamu makan dan pakai itu semuanya dari tanah belaka.

19) Wahai anakku! Jangan kamu melantik seseorang yang bodoh menjadi utusanmu. Jika tiada siapa yang lebih cerdas, pintar dan bijak maka yang sebaiknya dirimu sendirilah yang menjadi utusan.

20) Wahai anakku! Orang yang bersedia untuk mendengar nasihat dan bimbingan dari orang yang lebih alim, maka dia layak untuk mendapat penjagaan dari Allah tetapi bagi orang yang insaf dan sadar setelah menerima teguran maka dia lebih layak untuk mendapat kemulian dari Allah. 
21) Anakku, aku sudah pernah memikul batubatu besar, aku juga sudah mengangkat besibesi berat. Tapi tidak pernah kurasakan sesuatu yang lebih berat daripada tangan yang buruk perangainya.

22) Anakku, aku sudah merasakan semua benda yang pahit. Tapi tidak pernah kurasakan yang lebih pahit dari kemiskinan dan kehinaan

23) Anakku, aku sudah mengalami penderitaan dan bermacam kesusahan. Tetapi aku belum pernah merasakan penderitaan yang lebih susah daripada menanggung hutang.

24) Anakku, sepanjang hidupku aku berpegang pada delapan wasiat para nabi. Kalimat itu adalah:

(a) Jika kau beribadah pada Allah, jagalah pikiranmu baik-baik.

(b) Jika kau berada di rumah orang lain, maka jagalah pandanganmu

(c) Jika kau berada di tengah-tengah majelis, jagalah lidahmu

(d) Jika kau hadir dalam jamuan makan, jagalah perangaimu

(e) Ingatlah Allah selalu

(f) Ingatlah maut yang akan menjemputmu

(g) Lupakan budi baik yang kau kerjakan pada orang lain

(h)Lupakan semua kesalahan orang lain terhadapmu

\section{Klasifikasi Nasihat Luqman Berdasarkan}

\section{Ajaran Islam}

1. Dan ingatlah ketika Lukman berkata kepada anaknya (Tsaran) dan ia menasehatinya : Hai anaku janganlah kamu mempersekutukan Allah, sesungguhnya mempersekutukan Allah adalah benar-benar kezaliman yang besar," (Qs-Luqman (31: 13)

2. Hai anaku, sesungguhnya jika ada (sesuatu perbuatan) seberat biji sawi dan berada dalam batu atau di langit atau berada di dalam bumi, niscaya Allah akan mendatangkannya (membawanya) sesengguhnya Allah maha halus lagi maha mengetahui." (Qs-Luqman (31) : 16)

3. Hai anaku, dirikanlah shalat dan suruhlah (manusia) me-ngerjakan yang baik dan cegahlah (mereka) dari perbuatan yang mungkar dan bersabarlah terhadap apa yang menimpa kamu. Sesungguhnya yang demikian itu termasuk hal-hal yang diwajibkan (Allah)." (Qs-Luqman: 17)

4. Dan janganlah kamu memalingkan mukamu dari manusia (karena sombong) dan janganlah kamu berjalan dimuka bumi dengan angkuh. Sesungguhnya Allah tidak menyukai orang-orang yang sombong lagi membanggakan diri ( Qs-Luqman: 18)

5. Dan sederhanakanlah kamu dalam berjalan dan rendahkanlah suaramu. sesungguhnya seburuk-buruknya suara ialah suara keledai. (Qs-Luqman: 19)

\section{KESIMPULAN}

Setelah melakukan pembahasan, maka sebagai akhir dari penulisan skripsi ini perlu kiranya penulis menarik beberapa kesimpulan yang di perlukan. Adapun kesimpulan yang perlu penulis sam paikan adalah sebagai berikut : bahwa metode pendidikan anak yang terkandung dalam Al-Quran surat Luqman ayat 13 - 19 adalah: 1) Materi pendidikannya mencakup pendidikan Aqidah, pendidikan Syari'ah dan pendidikan Akhlak; 2) Metode pengajarannya dengan mauidloh dan tanya jawab; 3) Sifat pendidik mencakup bijaksana dan kasih sayang terhadap anak didik.

\section{DAFTAR PUSTAKA}

Abdurrahman, Laila binti. 2008. Cara Islami Sukses Mendidik Buah Hati. Klaten: Inas Media.

Achmad Djazuli, Penyelenggaraan Pendidikan di Sekolah Dasar, (Jakarta : Pen. Bag. Proy. Peningkatan Wawasan Pendidikan Guru Agama, 2005)

Ahmad D. Marimba, Seminar Pendidikan Agama Islam se Indonesia (Bogor: Cipayung, Tanggal 7-11 Mei 1960)

Ahmad Tafsir, Ilmu Pendidikan Islam Dalam Perspektif Islam, Remaja Rosdakarya, Bandung, 2001

Latif, Abdul Aziz bin Muhammad Ali Abdul. 1998. Pelajaran Tauhid untuk Lanjutan. Jakarata: as-Sofwa 
Niron, Dasar-dasar Ilmu Pendidikan Buku Panduan Mahasiswa, Jakarta: Gramedia Pustaka Utama, Cet. 2, 1996.

Ahmad D. Marimba, Pengantar Filsafat Pendidikan Islam, Al-Maarif, Bandung 1980

Ahmad Tafsir, Ilmu Pendidikan dalam Persepektif Islam. (Bandung: PT Remaja Rosdakarya)

Hamdani Bakran Adz-Dzakiey Kecerdasan Kenabian, (Yogyakarta, Penerbit Pustaka AlFurqan, (2006)

Hujair AH. Sanaky, Paradigma Pendidikan Islam; Membangun Masyarakat Indonesia, Yogyakarta: Safiria Insania Press dan MSI,

http://iklanbaris.kilu.de/pengertian-anakmenurut-para-ahli/ diakses tgl $28 \mathrm{Mei}$

http://duniapsikologi.dagdigdug.com/2008/11/ 19/pengertian-anak-tinjauan-secarakronologis- dan-psikologis/ diakses tgl 28 Mei

http://definisipengertian.blogspot.com/2010/05/pengerti an-anak.html

http://www.generasimuslim.com/mutiarahikmah/244-info-pendidikan-anak diakses $\operatorname{tgl} 21 \mathrm{Mei}$

http://cybercounselingstain.bigforumpro.com/il mu-pendidikan-islam-f17/ pengertianpendidikan islamt136.htm diakses tgl 14 Mei

Kemas Badaruddin, Filsafat Pendidikan Islam. (Yogyakarta: Pustaka Pelajar, 2007).

Ki Hajar Dewantara, Pendidikan Islam, (Jakarta: Genta Press, 1996),

Kemas Badaruddin, Filsafat Pendidikan Islam. (Yogyakarta: Pustaka Pelajar, 2007).

Muhammad 'Ali Quthb, Auladuna fi-Dlaw-it Tarbiyyatil Islamiyah, Terj. Bahrun Abu Bakar Ihsan, "Sang Anak dalam Naungan Pendidikan Islam”, Bandung : Diponegoro, Cetakan II, 1993

Muhibbin Syah M.Ed Pisikologi Pendidikan (Penerbit PT Remaja Rosda Karia Bandung cet, ke XI September 2005)

Tarazi Norma Wahai Ibu Kenali Anakmu, (Mitra Pustaka, Jakarta 1998)

Zakiah Daradjat, Pendidikan Agama Islam, (Jakarta: Rineka Cipta, 2002), 